https://doi.org/10.46344/JBINO.2021.v10i2b.04

\title{
AMIODARONE INDUCED THYROTOXICOSIS - REVIEW OF TREATMENT
}

\section{Em sutrisna}

Medical Faculty of Universitas Muhammadiyah Surakarta

\section{Email: es233@ums.ac.id}

\begin{abstract}
Amiodarone is derivative of benzofuran. This medicine was classified as class III anti-arrhythmic drug. Amiodarone is indicated to treat ventricular tachycardia and recurrent ventricular fibrillation. This medicine is a narrow therapeutic index. There are need therapeutic drugs monitoring to minimize adverse drug reaction (ADR). One of ADR of amiodarone therapy is amiodarone induced thyrotoxicosis (AIT). The review is aimed to determine the therapy of AIT. Review was performed by searching articles published in Pubmed and science direct by typing the keywords of "therapy" and "amiodaron induced thyrotoxicosis". Prednisone, perchlorate, methimazole and Iopanoic acid (IopAc) are used to treat AIT with various results.
\end{abstract}

Keywords: Amiodarone, narrow therapeutic index, adverse drug reaction. 


\section{Introduction:}

Amiodarone is a medicine widely used as anti-arrhythmic. This medicine is indicated to treat atrial ventricular fibrillation and supraventricular tachycardia (1). Amiodarone is narrow therapeutic index and has large variation in pharmacokinetics individual (2). The kinetic profile of amiodarone is as follows; The bioavailability of amiodarone varies in 35-65\%(3); Cmax 3-7 hours after administration, onset of action of amiodarone after one dose by IV route is between 1-30 minutes, SSC (Steady-state concentrations) in the plasma 0.4-11.99 $\mathrm{\mu g} / \mathrm{ml}(4,5) ; \quad T \mathrm{Vd}$ (volume of distribution) was $9.26-17.17 \mathrm{~L} / \mathrm{kg}$ in healthy volunteers and $6.88-21.05 \mathrm{~L} / \mathrm{kg}$ in the SVT patients(6); The protein binding of amiodarone is about $96 \%$ (4). Amiodarone is metabolized to desethylamiodarone/DEA (the main metabolite)(4) by the CYP3A4 and CYP2C8 enzymes. Elimination of amiodarone is by hepatic and biliary excretion (4). Desethylamiodarone (DEA) is found in the urine in a small amount(3).

Due to narrow therapeutix index, amiodararose often cause adverse drug reaction (ADR). One of it is hyrotoxicosis.
Amiodarone induced thyrotoxicosis (AIT) usually occurs after amiodarone withdrawal(7).

\section{Prevalence:}

AIT presents in $2-12 \%$ of patients treated byamiodarone. The incidence varies which is presumably influenced by iodine intake in this population. Several studies show that Central European populations are more frequently exposed to AIT. This is presumably because the population is low in iodine intake $(8,9,10)$.

\section{Mechanism:}

Amiodarone inhibit de-iodinasi T4 by 5' monodeiodinase. Amiodarone inhibits the activity of 5 'Type I monodeiodinase and causes inhibition of conversion of T4 to T3. This occurs after several months of amiodarone therapy that causes the decrease in T3 concentrations plasma and tissue, and the increase in the concentration of $T 4(8,9,11)$.

Amiodarone blocks the entry of thyroid hormones into the cell. The results of the kinetic study demonstrated the transfer of 44 from plasma to tissue as in the heart decreases. This reduces storage of intracellular T4 substrate thereby decreasing T3 production(9, 12).

\section{Therapy:}

There are two (2) studies with randomized trial therapy for AIT (table 1)

Table 1. Study of AIT therapy

\begin{tabular}{|c|c|c|c|c|c|}
\hline $\begin{array}{l}\text { Study } \\
\text { design }\end{array}$ & Population & Eligible criteria & $\begin{array}{l}\text { Treatmen } \\
\text { t/interven } \\
\text { tion }\end{array}$ & Outcome & Ref. \\
\hline $\begin{array}{l}\text { Randomi } \\
\text { zed } \\
\text { multicent } \\
\text { er study }\end{array}$ & $\begin{array}{l}\text { Patiesnt in } \\
\text { Dutch } \\
\text { hospitals }\end{array}$ & $\begin{array}{l}\text { Patients with AIT } \\
\text { type } 2 \text { (TSH }<0.4 \\
\text { mU/lt; FT4 }>25 \\
\text { pmol/lt; thyroid } \\
\text { peroxidase } \\
\text { antibodies }<50 \mathrm{kU} / \mathrm{lt} \\
\text { and TSH }\end{array}$ & $\begin{array}{l}3 \text { group: } \\
\text { predniso } \\
\text { ne }+ \\
\text { methima } \\
\text { zole }\end{array}$ & $\begin{array}{l}\text { TSH } \geq 0.4 \mathrm{mU} / \mathrm{lt} \text { on initial therapy }=12(100 \%) \text {. } \\
\text { TSH } \geq 0.4 \mathrm{mU} / \mathrm{t} \text { on additional therapy }=\mathrm{NA} \\
\text { Time to FT4 } \leq 25 \mathrm{pmol} / \mathrm{lt}(\mathrm{wk}) b=4(4-20) \\
\text { Time to TSH } \geq 0.4 \mathrm{mU} / \mathrm{lt}(\mathrm{wk}) b=8(4-20) \\
\text { Recurrent thyrotoxicosis- } 1 \\
\text { Time of recurrence }(\mathrm{wk})=24 \\
\text { Time to TSH } 0.4 \mathrm{mU} / \mathrm{lt}(\mathrm{wk})=8\end{array}$ & (13) \\
\hline
\end{tabular}


binding inhibitory

immunoglobulins < 2

U/lt; poor or no

visualization of

thyroid gland on

99mTc-pertechnetate

scintigraphy; no

nodular goiter (> one

nodule or a nodule 1

cm) on USG)
Perchlora

te+

methima

zol

(2)

predniso

ne

+ perchlo

rate+

methima

zole

Iopanoic

acid

zed

prospecti

ve

Patients of
Pisa
university,
Italia

Italia

\section{Discussion}

Patiens AIT
II(biochemical
hyperthyroidism;
absence of goiter,
absence of thyroidal
hypervascularization
on color flow
Doppler sonography
(CFDS); low (4\%) to
undetectable 24-h
thyroid radioiodine
uptake (RAIU);
absence of circulating
antithyroglobulin
(TgAb),
antithyroperoxidase
(TPOAb) and
anti-TSH receptor
(TRAb) antibodies

$\mathrm{TSH} \geq 0.4 \mathrm{mU} / \mathrm{lt}$ on initial therapy $=10(71 \%)$.

$\mathrm{TSH} \geq 0.4 \mathrm{mU} / \mathrm{lt}$ on additional therapy $=4(29 \%)$

Time to FT4 $\leq 25 \mathrm{pmol} / \mathrm{lt}$ (wk) $b=12(4-20)$

Time to $\mathrm{TSH} \geq 0.4 \mathrm{mU} / \mathrm{lt}(\mathrm{wk}) b=14(4-32)$

Recurrent thyrotoxicosis $=0$

Time of recurrence $(\mathrm{wk})=\mathrm{NA}$

Time to TSH $0.4 \mathrm{mU} / \mathrm{lt}$ (wk)=NA

$\mathrm{TSH} \geq 0.4 \mathrm{mU} / \mathrm{lt}$ on initial therapy $=10(100 \%)$.

$\mathrm{TSH} \geq 0.4 \mathrm{mU} / \mathrm{lt}$ on additional therapy= NA

Time to FT4 $\leq 25 \mathrm{pmol} / \mathrm{lt}$ (wk) $b=8(4-20)$

Time to TSH $\geq 0.4 \mathrm{mU} / \mathrm{lt}(\mathrm{wk}) b=12(4-28)$

Recurrent thyrotoxicosis $=2$

Time of recurrence $(\mathrm{wk})=12 \& 76$

Time to TSH $0.4 \mathrm{mU} / \mathrm{lt}(\mathrm{wk})=4$

(IopAc) $\quad$ serum FT4=2.90 $\pm 0.6 \mathrm{ng} / \mathrm{dl}$ to $2.30 \pm 0.4 \mathrm{ng} / \mathrm{dl}, P 0.39$

Serum TSH $(\mathrm{U} / \mathrm{ml})=$ normal range after $84 \pm 43$ day

Predniso Serum-free T3 $(\mathrm{ng} / \mathrm{dl})=0.58 \pm 0.10 \mathrm{ng} / \mathrm{dl}$ to $0.34 \pm 0.03$

ne

ng/dl $P 0.003$ (7days therapy)

serum FT4= $2.70 \pm 0.32 \mathrm{ng} / \mathrm{dl}-1.0 \pm 0.04 \mathrm{ng} / \mathrm{dl} \mathrm{ng} / \mathrm{dl}, P$ 0.0001

Serum TSH $(\mathrm{U} / \mathrm{ml})=$ normal range after $40 \pm 34$ day

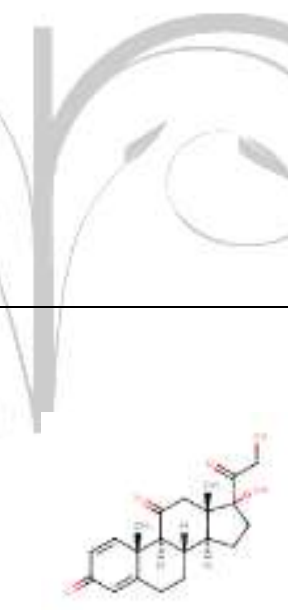

Fig 1. Structure of Prednisone(15)

Perchlorate $\left(\mathrm{ClO}_{4}\right)$ improves AIT by inhibition uptake of thyroidal iodine thus decreases production of thyroid hormone (T3 \&T4) (17). This medicine has molecular weight 99.451 (average)(18).

in the liver to prednisolone (active form). Prednisolone is a corticosteroid agonist. The molecular weight of Prednisone is 358.4281 (average)(15). This medicine poses inflammatory process of AIT(16).<smiles>O=S(=O)([O-])OCCCCCCCO</smiles>

Fig.2 Structure of perchlorate(18) 
Methimazole can be used to treat AIT. The main mechanism of action of methimazole is to block the production of thyroid hormone from the thyroid gland thereby preventing the synthesis of thyroxine (T4) and tri-iodothyronine (T3) (19); interfere with the oxidation of iodide ions and iodothyrosyl groups. This causes a decrease of thyroglobulin and circulating thyroid hormone levels $(19,20)$. Methimazole has molecular Weight of 114.1699 (average)(19).

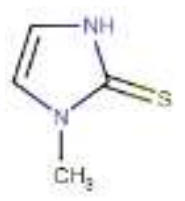

Fig.3 Structure of methimazole(21)

lopanoic acid belongs to the group of oral cholecystographic agents (OCA). This drug has been used to treat hyperthyroidism because of its fast effect and excellent safety(22-24). This medicine inhibits deiodination which is responsible for peripheral conversion of T4 to T3(23). In particular, these agents inhibit the deiodination of the outer ring of $\mathrm{T} 4$ to the active metabolites T3, but does not affect the inner ring deiodination from T4 to 3,3 ', 5'-triiodothyronine (reverse T3, rT3)(11). Reverse T3 (rT3) can inhibit monodeiodination T4 to T3(25). IopAC controls thyrotoxicosis in the short term due to its peripheral effects(26). Iopanoic acid has molecular weight of 570.9319(27).

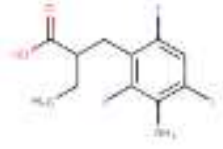

Fig 4. Structure of Iopanoic acid(27)

\section{Conclusion}

Therapy of AIT by prednisone, perchlorate, methimazole and lopanoic acid (IopAc) has various results. Time to FT4 25 pmol/liter (wk) of therapy by prednisone +methimazole is faster 4 (4-20) than Perchlorate+ methimazol and Perchlorate+ prednisone +methimazol. Time to TSH 0.4 $\mathrm{mU} /$ liter (wk) of therapy by prednisone +methimazole is faster 8 (4-20) than Perchlorate+ methimazol and Perchlorate+ prednisone +methimazol. Perchlorate and methimazole give the best results in relation to the absence of recurrent toxicity.

IopAc and glucocorticoid therapy can reduce FT3 serum levels rapidly. However, patients treated by lopAc take longer time than patients treated by glucocorticoids therapy to reach normal serum FT4 level. This happens due to the facts that IopAc only exerts its effect on changing T4 to T3 and it does not affect the underlying destructive thyroiditis. IopAc controls thyrotoxicosis in the short term due to its peripheral effects.

Prednisone alone can reduce FT4 level significantly (but not lopAc). It is allegedly prednisone has inhibitory effect on I 5-deiodinase activity and poses inflammatory in thyroid thus reducing serum FT4 levels.

\section{References}

1. https://go.drugbank.com/drugs/DB01118]

2. Vyskocilovaa EH, Grundmanna $M$, Duricovaa, J, Kacirovaa I, Therapeutic monitoring of amiodarone: Pharmacokinetics and evaluation of the relationship between effect and dose/concentration, Biomed Pap Med Fac Univ Palacky Olomouc Czech Repub. 2017, 161 (2):134-143 
3. FDA Approved Drug Products: Cordarone (amiodarone $\mathrm{HCl}$ ) tablets

4. Latini R, Tognoni G, Kates RE: Clinical pharmacokinetics of amiodarone. Clin Pharmacokinet. 1984, 9(2):136-56.

5. Zipes DP, Prystowsky EN, Heger JJ: Amiodarone: electrophysiologic actions, pharmacokinetics and clinical effects. J Am Coll Cardiol. 1984,3(4):1059-71.

6. Riva E, Gerna M, Latini R, Giani P, Volpi A, Maggioni A: Pharmacokinetics of amiodarone in man. J Cardiovasc Pharmacol. 1982,4(2):264-9.

7. Yagishita, $A$; Hachiya, $H$; Kawabata, $M$; Nakamura T; Sugiyama, K; Tanaka, Y; et al., Amiodarone-Induced Thyrotoxicosis Late After Amiodarone Withdrawal, Circulation Journal ,2013,77(12): 2898-903

8. Loh KC. Amiodarone-induced thyroid disordes; a clinical review, Postgrad Med J. 2000;76:133-40.

9. Martino E, Bartalena L, Bogazzi F. The effect of amiodarone on the thyroid. Endocrine Reviews. 2001;22(2):240-54

10. Thorne SA, Barnes I, Cullinan P, Somerville J. Amiodarone-associated thyroid dysfunction. Risk factors in adults with congenital heart disease. Circulation. 1999, 100:149-54

11. Harjai K, Licata A. Effects of amiodarone on thyroid function. Annals of Internal Medicine. 1997, 126:63-73.

12. de Jong $M$, Docter $R$, van der Hoek $H$, Krenning E, van der Heide D, Quero C, et al. Different effects of amiodarone on transport of T4 and T3 into the perfused rat liver. Am J Physiol. 1994, 266(1):E44-49

13. Silvia A. Eskes, Erik Endert, Eric Fliers, Ronald B. Geskus, Robin P. F. Dullaart, Thera P. Links, and Wilmar M. Wiersinga
Treatment of Amiodarone-Induced ThyrotoxicosisType 2:A Randomized Clinical Trial, The Journal of Clinical Endocrinology and Metabolism, 201 1, 97(2):499-506

14. Bogazzi F, Bartalena L, Cosci C, Brogioni S, Dell'Unto E, Grasso L, Aghini-Lombardi F, Rossi G, Pinchera A, Braverman LE, Martino E, Treatment of type Il amiodaroneinduced thyrotoxicosis by either iopanoic acid or glucocorticoids: a prospective, randomized study.. J Clin Endocrinol Metab. 2003, 88(5):1999-2002.

15. https://go.drugbank.com/drugs/DB00635.

16. Bartalena L, Bogazzi F, Martino E 2002 Amiodarone-induced thyrotoxicosis: a difficult diagnostic and therapeutic challenge. Clin Endocrinol 56:23-24

17.Leung, AM, Pearce EN, Braverman,LE , Perchlorate, iodine and the thyroid, Best Pract Res Clin Endocrinol Metab., 2010, 24(1): 133-141.

18. https://go.drugbank.com/drugs/DB03138

19. Abraham P, Acharya S. Current and emerging treatment options for Graves' hyperthyroidism. Ther Clin Risk Manag. 2010, 02(6):29-40.

20. Sonnet E, Massart C, Gibassier J, Allannic H, Maugendre D. Longitudinal study of soluble intercellular adhesion molecule-1 (ICAM-1) in sera of patients with Graves' disease. J Endocrinol Invest. 1999, 22(6):430-5.

21.https://go.drugbank.com/drugs/DB00763

22. Bal C, Nair N. The therapeutic efficacy of oral cholecystographic agent (iopanoic acid) in the management of hyperthyroidism. J Nucl Med 1990, 31:11801182.

23. Braga M, Cooper DS. Clinical review 129: Oral cholecystographic agents and the 
thyroid. J Clin Endocrinol Metab, 2001, 26.Roti E, Colnjani R, Braverman LE, Adverse 86:1853-1860. effects of iodine on the

24. Panzer C, Beazley R, Braverman L. Rapid preoperative preparation for severe thyroid. The Endocrinologist, 1997, 7:245254

hyperthyroid Graves' disease. J Clin 27.https://go.drugbank.com/drugs/DB08946 Endocrinol Metab 2004, 89:2142-2144.

25. Larson FC, Albright EC. Inhibition of Lthyroxine monodeiodination by thyroxine analogs. J Clin Invest 1961,40:1132-1138 